\title{
DISCURSO DA SRA. MARIA DA GRAÇA SIMÕES CÔRTE IMPERIAL NA TRANSMISSÃO DO CARGO DE PRESIDENTE DA ABEn NA POSSE DOS MEMBROS ELEITOS PARA O PERIODO DE $1976 / 1980$. EM 18/8/1976
}

Desde o momento em que cruzamos os umbrais da Escola de Enfermagem, onde nos preparamos para o exercício de uma das mais belas profissōes, nossas forças se desgastam num trabalho contínuo pela recuperaçāo dos que sofrem. Traçamos, voluntariamente, um destino onde não há alternativa entre o bem e o mal e onde há de prevalecer a força ae nosso ideal que assim se define na profissāo de enfermeira: abnegaçāo, fé cristā, sacrifício pelos interesses superiores da humanidade, compreensão da vida no plano divino da virtude, tudo que alheia o homem na própria individualidade e o eleva e multiplica, o agiganta, por uma contemplaçāo pura, uma resoluçāo heróica ou uma aspiraçāo sublime. Não é outra a nossa missão, não é outro o nosso dever.

Mais uma vez estamos diante do órgāo soberano da Associaçāo Brasileira de Enfermagem, no intuito de prestar contas das atividades da ABEn, gestão da Diretoria que hoje encerra seus trabalhos.

De acordo com o primeiro Relatório da atual Diretoria apresentado pela Dra. Glete de Alcântara à Assembléia de Delegados no XXV Congresso Brasileiro de Enfermagem na Cidade de Joāo Pessoa, na Paraíba, ficou determinado que nāo iríamos apresentar um novo programa de ação, e sim dar continuidade às obras e trabalhos iniciados por Diretorias anteriores os quais careciam de uma solução imediata e definitiva. No referido Relatório, as metas prioritárias se consubstanciavam nas seguintes conquistas:

1. O Projeto de Lei criando os Conselhos Federal e Regionais de Enfermagem, votado na época pelo Congresso Nacional e em vias de ser sancionado pelo Excelentíssimo Senhor Presidente da República. Assim, graças à participaçāo devotada dos parlamentares e dos membros da Diretoria da ABEn, este marco fundamental e de legítimo interesse para as atividades da enfermagem, foi concretizado pela Lei n. ${ }^{\circ} 5.905$ de 12-07-1973;

2. As obras de construção da sede da ABEn, em Brasilia, que se encontravam terminadas, faltando detalhes de equipamento, decoraçāo de interiores, bem assim a transferência definitiva do órgão. Hoje, a Sede da Associação Brasileira de Enfermagem, em Brasilia, está em condiçōes de cumprir com suas finalidades;

3. A revisão dos Estatutos da ABEn, tarefa que demandava tempo e açāo, estudo de várias Diretorias que para tanto contou com a colaboração valiosa de Comissōes Especiais e, assessoramento juridico além da participaçāo das Sessōes da ABEn que enviaram sugestōes de seus associados, tendo sido aprovadas as suas 
Reformas na Assembléia de Delegados realizada nos dias 10 e 11 do corrente, neste Congresso;

4. O documentário sobre o histórico da ABEn, sonho de várias Diretorias, finalmente editado. Evidentemente que, sem a cooperação e o incentivo de muitos, não poderíamos ter concluído esies trabalhos;

Ao término do mandato que hoje se extingue, desejo agradecer à equipe que comigo atuou de novembro de 1974 a agosto de 1976 pelo elan demonstrado ao enfrentar as dificuldades com aquela fé, domínio e dedicaçāo que caracterizam a superioridade espiritual e 0 desprendimento dos que colocam sua visão acima das vicissitudes. Agradeço-lhes outrossim o entusiasmo e a humildade com que receberam as vitórias conseguidas mercê de Deus, supremo realizador e juiz de uma nobre causa.

Ao ensejo desta transmissão dos cargos à nova Diretoria e ao outorgar à Enfermeira Iêda Barreira e Castro, a comenda de Presidente, que expressa o supremo poder da Associação Brasileira de Enfermagem, quero manifestar meus votos de sucesso na sua gestāo e as suas companheiras de Diretoria, ao tempo em que afirmo a nossa disposição de emprestar o apoio de que dispomos para o êxito de sua missão. 